\title{
Prevalence of Gastro Intestinal Parasites in Sheep of Assam, India
}

\author{
K. Bhattacharjee*, S. Bora and D. K. Deka \\ Department of Parasitology, College of Veterinary Science, Assam Agricultural University, \\ Khanapara, Guwahati-781022, Assam \\ *Corresponding author
}

\section{A B S T R A C T}

Keywords

GI parasitism,

Prevalence, Sheep, Agroclimatic zone, Assam, Age, Sex, Strongyle

Article Info

Accepted:

15 January 2021

Available Online:

10 February 2021
Gastrointestinal (GI) parasitism in small ruminants is one of the major problems in the Indian subcontinent. The resent study was designed to generate prevalence data on GI parasitism of sheep in 7 different districts comprising 6 Agroclimatic zones of Assam, India. During 24 months study period, out of 334 faecal samples examined, 123 were found to be positive for gastrointestinal parasites (prevalence $36.82 \%$ ) and the highest prevalence recorded was $47.14 \%$ in Biswanath Chariali district and lowest $20 \%$ in Dhubri district. In sheep, prevalence was found highest in North Bank Plain (47.14\%) followed by Hills Temperate (40.74\%) and Lower Brahmaputra Valley (32.38\%). Age wise prevalence was $48.29 \%$ in adults and $18.60 \%$ in young. Sex wise prevalence indicated that the females were slightly more infected i.e. 39.15\%, than the males (33.79\%). Species of gastrointestinal nematode eggs recorded on microscopic examination of faecal samples were viz. Chabertia ovina, Trichuris ovis, Trichostrongylus spp., Haemonchus contortus and Oesophagostomum spp. eggs amongst the Strongyle nematodes, oocysts of coccidia and amphistome eggs amongst the trematodes. Chabertia ovina was found to be the predominant species.

\section{Introduction}

Nematode parasitic infections of sheep are a major problem throughout the world and are responsible for economic losses in a variety of ways. Recurring losses in productivity due to widely prevalent parasitic infection is an important and common problem for small ruminant production in most parts of the world (Singh et al., 2013). Gastrointestinal nematodes have been recognized as a major factor limiting sheep production throughout the world (Kuchai et al., 2011). These parasites cause both acute infections with a rapid onset and high mortality levels and chronic infections, which are commonly subclinical and may lead to insidious and important economic losses via reduction of live weight gain, reduced wool and milk production, and poor reproductive 
performance (Singh et al., 2017). Sheep are usually more prone to gastrointestinal tract (GIT) parasitism as they mostly graze on pastures contaminated with L3 of parasitic nematodes (Tariq et al., 2008). The prevalence of helminths of small ruminants results in low productivity due to stunted growth, poor weight gain and poor utilization. Commonly occurring gastrointestinal parasitic diseases in goats and sheep are Haemonchosis, Ostertagiasis, Strongyloidosis, Oesophagostomiasis, Bunostomiasis and Trichostrongylosis (Singh et al., 2013). Studies dealing with the prevalence and distribution of parasites of sheep in Assam state are very limited or absent, so this study was undertaken to record the prevalence of various GI parasites of sheep in this region of the country.

The results thus obtained from this study would be beneficial to devise appropriate and effective control strategies and prophylactic measures in sheep unique to this climatic zone and other parts of the world with similar climatic and husbandry production systems.

\section{Materials and Methods}

During 2 years of study period (April 2018March 2020), a total of 334 faecal samples collected from different districts of Assam. According to Agroclimatic zones, Assam is divided into 6 zones, however, the sheep population was available only in the following 7 districts under 3 Agroclimatic zones viz. Hills Temperate (Karbi Anglong); Lower Brahmaputra Valley (Bongaigaon, Dhubri, Goalpara, Kamrup, Baksa), North Bank Plain (Biswanath Chariali) (Table 1). Faecal samples were freshly collected per rectum from each animal and examined by floatation and sedimentation methods (Zajac and Conboy, 2012). In the positive samples, egg per gram (EPG) of faeces was done using Mc Master egg counting chamber. Sheep were divided into two groups according to their age as kids (6 months-1 year) and adults (>1 year). The sheep examined were of indigenous breed and of either sex.

\section{Results and Discussion}

In the present study, out of 334 faecal samples examined, 123 were found to be positive for gastrointestinal parasites (prevalence 36.82\%) (Table-2) and the highest prevalence recorded was $47.14 \%$ in Biswanath Chariali and lowest $20.00 \%$ in Dhubri district.

The EPG range was 100-1200. Age wise prevalence revealed that the adults were more prone to infection (Table-3), with a prevalence of $48.29 \%$ followed by the young ones i.e. $18.60 \%$. Sex wise prevalence (Table-4) indicated the females were more infected i.e. $39.15 \%$ than the males $(33.79 \%)$.

Species of gastrointestinal parasitic eggs recorded on microscopic examination of faecal samples in order of predominance were viz. Chabertia ovina, Haemonchus contortus, Oesophagostomum spp., Trichostrongylus spp. and Trichuris ovis, amongst the Strongyle nematodes, oocysts of Coccidia and Amphistome eggs amongst the trematodes.

District wise data in the present study revealed that out of 334 faecal samples examined, 123 were found to be positive for gastrointestinal parasites (prevalence 36.82\%) and the highest prevalence recorded was $47.14 \%$ in Biswanath Chariali district and lowest $20.00 \%$ in Dhubri district.

Species of gastrointestinal nematode eggs recorded on microscopic examination of faecal samples were viz. Chabertia ovina, Trichuris ovis, Haemonchus contortus and Oesophagostomum spp. eggs amongst the Strongyle nematodes, oocysts of coccidia and amphistome eggs amongst the trematodes. 
This can be regarded as the first study on prevalence of G.I. parasites in sheep in this region of the country. Although, in India, there are several reports on prevalence of G.I. nematodes in sheep from different parts of the country (Tariq et al., 2008; Kuchai et al., 2011, Bhat et al., 2012; Meenakshi sundaram et al., 2014; Singh et al., 2017 etc.), no pertinent literature in this regard is available from this region to compare our data, as most of the works having been carried out earlier in goats and cattle.

Tariq et al., in 2008 carried out prevalence study for two years in the Kashmir valley wherein the recorded the overall prevalence of GI nematodes in sheep in the $1^{\text {st }}$ and $2^{\text {nd }}$ year as 64.76 and $58.37 \%$ respectively.

The parasites recorded in their study were Haemonchus contortus, Ostertagia circumcincta, Bunostomum trigonocephalum, Chabertia ovina, Trichostrongylus spp., Nematodirus spathiger, Oesophagostomum columbianum, Trichuris ovis and Marshallagia marshalli, in varying percentages. Kuchai et al., (2011) recorded a prevalence percentage of $43.45 \%$ in sheep of Ladakh due to four species of nematodes viz. Trichuris ovis, Haemonchus contortus, Dictyocaulus filaria and Chabertia ovina. It was also observed that among these, T. ovis was followed by $H$. contortus, D. filaria and C. ovina, respectively.

They could also draw an association of prevalence with season, sex, age and agroecology. Singh et al., in 2017 conducted a prevalence study of gastrointestinal parasitism in small ruminants in western zone of Punjab, India wherein they recorded $85.16 \%$ prevalence in sheep and further they could draw the inference that the most relevant risk factors for the prevalence of GI parasitism in ruminants were sex, age, and season. In most of the studies conducted all over India, it was observed that Chabertia ovina was the pre dominant nematode species, which is in accordance with our study.

Our findings also reveal the presence of oocysts of Coccidia and Amphistome eggs apart from the GI nematode eggs.

In our study, age wise prevalence was $48.29 \%$ in adults and that in young was $18.60 \%$ i.e. the adults were infected more as compared to the young ones. However, Tariq et al., (2008) recorded that lower age groups were more infected than adult animals but Singh et al., 2017 opined that adults (>6 months) were significantly prone to parasitic infection as compared to young ones ( $<6$ months), which is similar in our case also, although the age range considered were slightly different in the two studies.

From the data, it could be inferred that higher nematode prevalence in adults might be due to grazing on larger area of pastures being contaminated with various flocks and different stress conditions such as climate, daily travelling, and gestation (Radostits et al., 1994).

In the present study, the sex wise data revealed that the females $(39.15 \%)$ were slightly more infected than their male counterparts (33.79\%), which is in accordance with Singh et al., (2017) but Tariq et al., (2008) found that prevalence was higher in rams (males) than eves (females).

This could be due to the physiological peculiarities of the female animals, which usually constitute stress factors thus, reducing their immunity to infections, and for being lactating mothers, females happen to be weak/malnourished, as a result of which they are more susceptible to the infections besides some other reasons (Blood and Radostists, 2000) (Fig. 1-4). 
Table.1 Agroclimatic Zone wise samples collected from sheep in Assam

\begin{tabular}{|c|c|c|}
\hline Agroclimatic zone & District & $\begin{array}{c}\text { Total no. of samples } \\
\text { examined }\end{array}$ \\
\hline Hills Temperate & Karbi Anglong & 54 \\
\hline \multirow{2}{*}{ Brahmaputra } & Bongaigaon & 74 \\
\cline { 2 - 3 } & Dhubri & 10 \\
\cline { 2 - 3 } & Goalpara & 72 \\
\cline { 2 - 3 } & Kamrup & 36 \\
\cline { 2 - 3 } North Bank Plain & Baksa & 18 \\
\hline \multicolumn{2}{|c|}{ Biswanath Chariali } & 70 \\
\hline
\end{tabular}

Table.2 Prevalence of G.I. Parasites in sheep in different districts of Assam

\begin{tabular}{|c|c|c|c|c|c|}
\hline SL.No. & District & $\begin{array}{l}\text { Total no. } \\
\text { of samples } \\
\text { examined }\end{array}$ & $\begin{array}{c}\text { No. } \\
\text { positive }\end{array}$ & $\begin{array}{c}\text { Prevalence } \\
\%\end{array}$ & Species recorded \\
\hline 1. & Baksa & 18 & 4 & 22.22 & $\begin{array}{l}\text { Oocysts of Coccidia, } \\
\text { Amphistome eggs }\end{array}$ \\
\hline 2. & $\begin{array}{l}\text { Biswanath } \\
\text { Chariali }\end{array}$ & 70 & 33 & 47.14 & $\begin{array}{c}\text { Chabertia ovina eggs, } \\
\text { Haemonchus contortus } \\
\text { eggs, Oesophagostomum } \\
\text { spp. }\end{array}$ \\
\hline 3. & Bongaigaon & 74 & 31 & 41.89 & $\begin{array}{l}\text { Chabertia ovina eggs, } \\
\text { Haemonchus contortus, } \\
\text { Trichuris ovis eggs, } \\
\text { Oocysts of Coccidia }\end{array}$ \\
\hline 4. & Dhubri & 10 & 2 & 20.00 & $\begin{array}{l}\text { Trichostrongylus spp. egg, } \\
\text { Haemonchus contortus } \\
\text { eggs, Amphistome eggs }\end{array}$ \\
\hline 5. & Goalpara & 72 & 19 & 26.39 & $\begin{array}{l}\text { Chabertia ovina eggs, } \\
\text { Oesophagostomum spp. } \\
\text { eggs, Oocysts of Coccidia, } \\
\text { Amphistome eggs }\end{array}$ \\
\hline 6. & Kamrup & 36 & 12 & 33.33 & $\begin{array}{l}\text { Oocysts of Coccidia, } \\
\text { Trichostrongylus spp eggs, } \\
\text { Trichuris ovis eggs }\end{array}$ \\
\hline 7. & Karbi Anglong & 54 & 22 & 40.74 & $\begin{array}{l}\text { Chabertia ovina eggs, } \\
\text { Haemonchus contortus, } \\
\text { Oocysts of Coccidia, } \\
\text { Amphistome eggs }\end{array}$ \\
\hline & Total & 334 & 123 & & 36.82 \\
\hline
\end{tabular}


Table.3 Age wise prevalence of G.I parasites of sheep in Assam

\begin{tabular}{|c|c|c|c|}
\hline Age group & $\begin{array}{c}\text { No. of animals } \\
\text { examined }\end{array}$ & No. Positive & Prevalence \% \\
\hline Young & 129 & 24 & 18.60 \\
\hline Adult & 205 & 99 & 48.29 \\
\hline Total & $\mathbf{3 3 4}$ & $\mathbf{1 2 3}$ & $\mathbf{3 6 . 8 2}$ \\
\hline
\end{tabular}

Table.4 Sex wise prevalence of G.I parasites of sheep in Assam

\begin{tabular}{|c|c|c|c|}
\hline Sex & $\begin{array}{c}\text { No. of animals } \\
\text { examined }\end{array}$ & No. positive & Prevalence \% \\
\hline Male & 145 & 49 & 33.79 \\
\hline Female & 189 & 74 & 39.15 \\
\hline Total & $\mathbf{3 3 4}$ & $\mathbf{1 2 3}$ & $\mathbf{3 6 . 8 2}$ \\
\hline
\end{tabular}

Fig.1 Graph indicating prevalence of G.I parasites of sheep in Assam

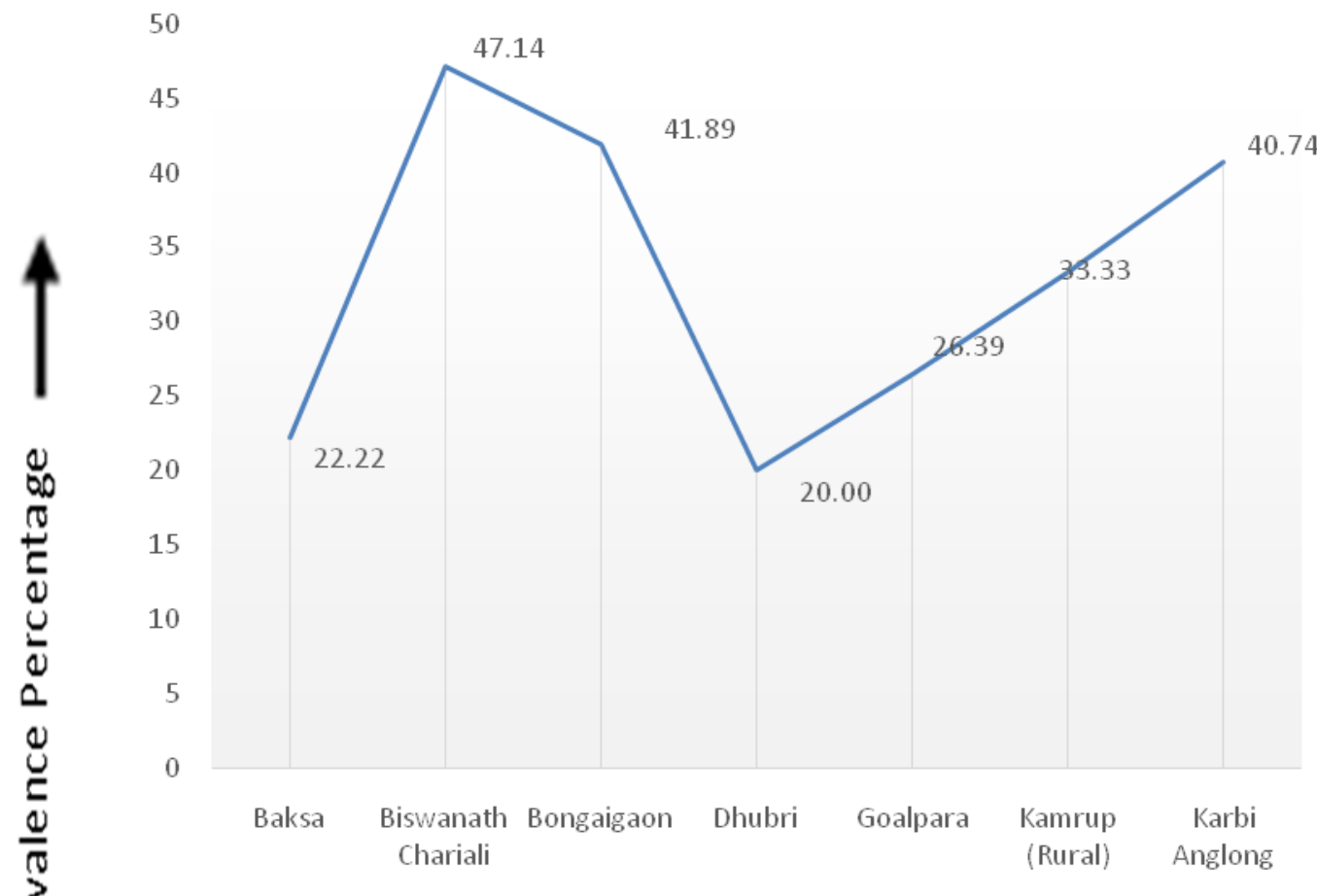

Districts of Assam 
Fig.2 Graph indicating age wise prevalence of G.I parasites of sheep in Assam

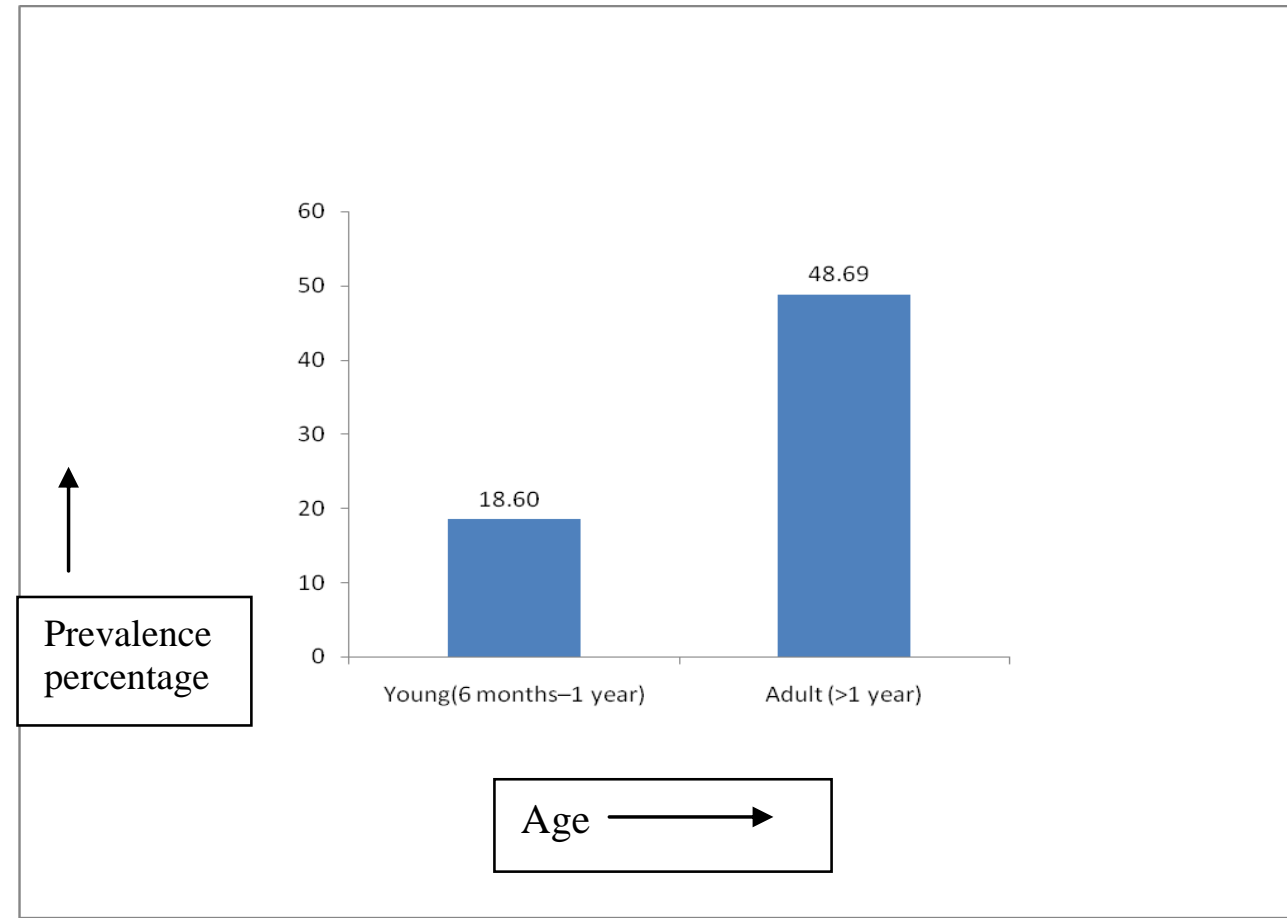

Fig.3 Graph indicating sex wise prevalence of G.I parasites of goats in Assam

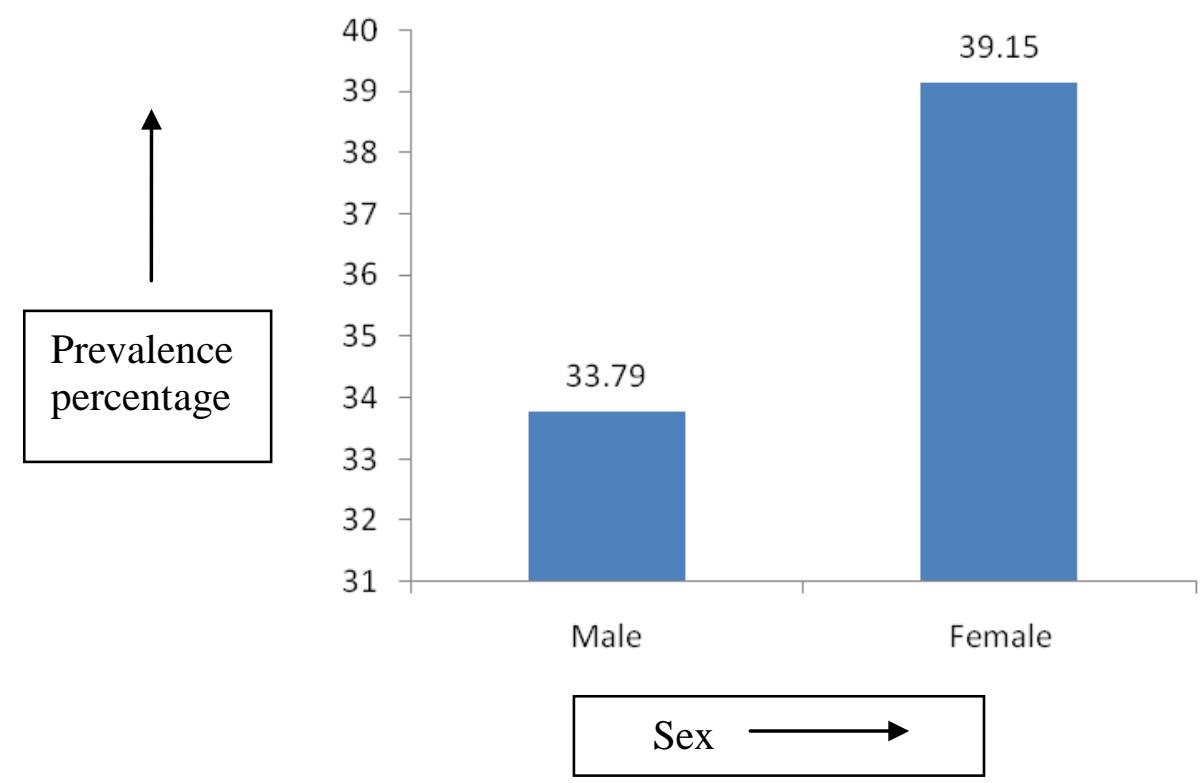


Fig.4

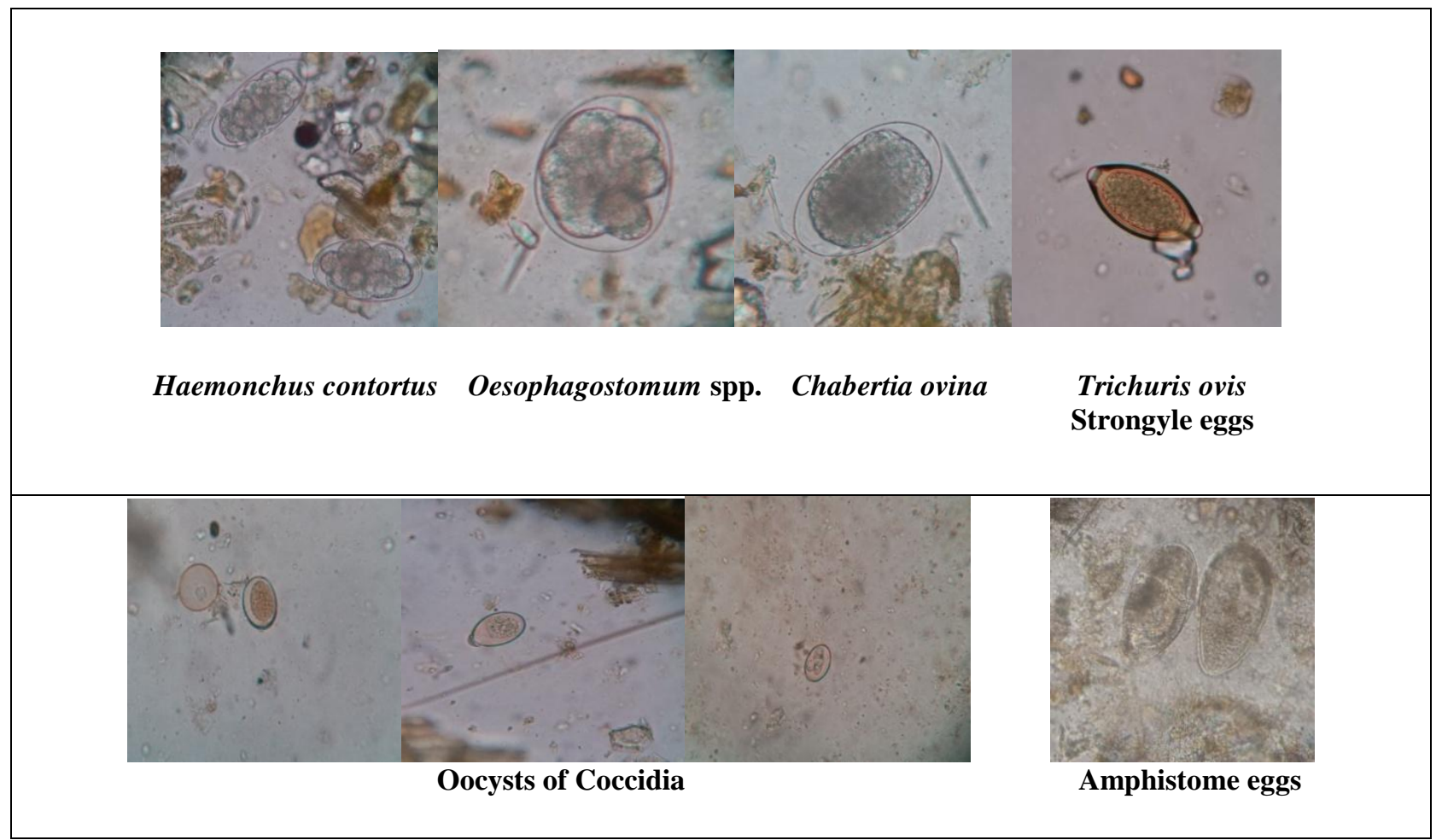

Thus, it can be concluded that parasite prevalence studies are of utmost importance to know the risk factors associated with the disease to devise effective control strategies for the same. Our present study revealed that the climatic zones, age and sex have significant effect on prevalence of gastrointestinal parasites. Necessary steps should be taken in timely manner to tackle this problem and improve the productivity of these animals. The data generated from the present study will be of immense help to the farmers for improving the farm conditions by effective management as this kind of information is not available from this part of the country.

\section{Acknowledgments}

The authors duly acknowledge the ICAR, New Delhi, India for providing the financial assistance in the form of "All India Network Programme on Gastrointestinal Parasitism".

\section{References}

Bhat, S.A., Mir, M., Qadir, S., Allaie, I.M., Khan, H.M., Husain and Sheikh, B.A. 2012. Prevalence of gastro-intestinal parasitic infections in Sheep of Kashmir valley of India. Veterinary World. 5(11): 667-671

Blood D.C. and Radostitis O.M. (2000) Veterinary Medicine. $7^{\text {th }}$ ed. The English Language Book Society, Bailliere Tindall, London.

Kuchai, J.A., Chishti, M.Z., Zaki, M.M., Ahmad, J., Rasool, M., Dar S.A. and Tak H. 2011. Prevalence of nematode parasites in Sheep of Ladakh- India Journal of Agricultural Extension and Rural Development. 3(13):229-231

Meenakshisundaram A., Anna T. and Harikrishnan J. 2014. Prevalence of drug resistant gastrointestinal nematodes in an organized sheep farm, 
Veterinary World.7(12): 1113-1116.

Radostits, O.M., Blood, D.C. and Gay, C.C. 1994. Veterinary Medicine. Bailliere Tindall, London.

Singh, E., Kaur, P., Singla, L.D. and Bal, M.S.. 2017. Prevalence of gastrointestinal parasitism in small ruminants in western zone of Punjab, India. Veterinary World.10(1): 61-66.

Singh, V., Varshney, P., Dash, S.K. and Lal, H.P. 2013. Prevalence of gastrointestinal parasites in sheep and goats in and around Mathura, India. Veterinary World. 6(5): 260-262

Tariq, K.A., Chishti, M.Z., Ahmad, F. and Shawl, A.S. 2008.Epidemiology of gastrointestinal nematodes of sheep managed under traditional husbandry system in Kashmir valley. Veterinary Parasitology. 158: 138-143

Zajac AM, Conboy GA (2012) Veterinary clinical parasitology, 8thedn. Wiley, UK, pp. 3-170.

\section{How to cite this article:}

Bhattacharjee, K., S. Bora and Deka, D. K. 2021. Prevalence of Gastro Intestinal Parasites in Sheep of Assam, India. Int.J.Curr.Microbiol.App.Sci. 10(02): 1805-1812.

doi: https://doi.org/10.20546/ijcmas.2021.1002.213 